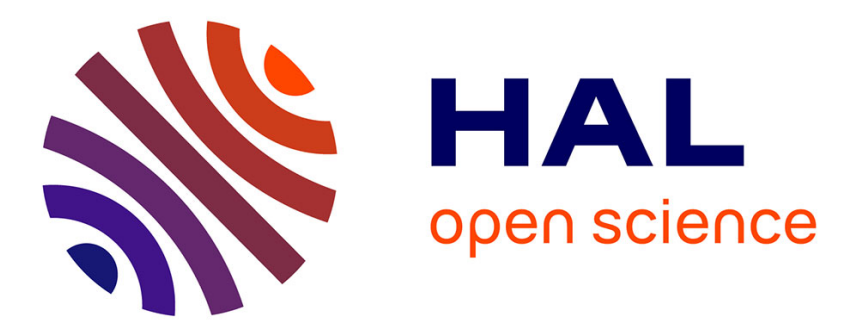

\title{
A thermodynamical model of molecular beam epitaxy, application to the growth of II VI semiconductors
}

J.P. Gailliard

\section{To cite this version:}

J.P. Gailliard. A thermodynamical model of molecular beam epitaxy, application to the growth of II VI semiconductors. Revue de Physique Appliquée, 1987, 22 (6), pp.457-463. 10.1051/rphysap:01987002206045700 . jpa-00245560

\section{HAL Id: jpa-00245560 https://hal.science/jpa-00245560}

Submitted on 1 Jan 1987

HAL is a multi-disciplinary open access archive for the deposit and dissemination of scientific research documents, whether they are published or not. The documents may come from teaching and research institutions in France or abroad, or from public or private research centers.
L'archive ouverte pluridisciplinaire HAL, est destinée au dépôt et à la diffusion de documents scientifiques de niveau recherche, publiés ou non, émanant des établissements d'enseignement et de recherche français ou étrangers, des laboratoires publics ou privés. 


\title{
A thermodynamical model of molecular beam epitaxy, application to the growth of II VI semiconductors
}

\author{
J. P. Gailliard \\ CENG-LETI, Laboratoire Infrarouge, 85 X, 38041 Grenoble Cedex, France
}

(Reçu le 17 novembre 1986, accepté le 13 février 1987)

\begin{abstract}
Résumé. - Nous présentons un modèle thermodynamique de l'épitaxie par jets moléculaires. Nous illustrons tout d'abord l'équilibre d'un composé et d'un alliage par les cas de $\mathrm{HgTe}$ et $\mathrm{CdHgTe}$. Nous faisons l'hypothèse que les flux se ré-évaporant du composé en cours de croissance sont liés par la loi d'action de masse exprimée en flux. Un bilan des espèces arrivant ou quittant la surface peut alors être écrit et conduit à un système d'équations dont la solution donne la vitesse de croissance, la composition $x$ de l'alliage ternaire, l'excès éventuelle d'une des espèces, le coefficient d'incorporation. Des résultats de calcul pour CdTe et CdHgTe comparés aux résultats expérimentaux montrent la validité des prévisions de ce modèle, dont l'intérêt principal est de permettre d'évaluer l'influence de la modification d'un paramètre de croissance. La validité de ce modèle est cependant limitée si la cinétique des réactions ne permet pas d'atteindre l'équilibre ; ce n'est pas le cas pour les alliages II VI étudiés ici.
\end{abstract}

\begin{abstract}
We present a model of molecular beam epitaxy based on thermodynamics. The equilibrium between a compound or a ternary alloy with the gas phase is illustrated in the case of $\mathrm{HgTe}$ and $\mathrm{CdHgTe}$. The meaning of equilibrium pressure is analysed and we make the assumption that the fluxes leaving the actual growing compound are linked by the mass action law where the pressures are transformed into the equivalent fluxes. A detailed balance of the species leaving or arriving at the surface is then possible and leads to a set of equations which can be solved to predict the growth rate, the $x$ value of a ternary alloy, the excess of one of the species, the incorporation coefficient. Examples of calculation are shown for $\mathrm{CdTe}$ and $\mathrm{Cd}_{x} \mathrm{Hg}_{1-x} \mathrm{Te}$ and are compared with experimental results and show a good agreement. The main interest of this model resides in its ability to predict the effects of the modification of one of the growth parameter. Nevertheless it predicts only the limit conditions which are not necessary reach due to the kinetic of the reactions.
\end{abstract}

\section{Introduction.}

Molecular beam epitaxy is now a well established technique which has proved successfull for growth of high quality thin layers of semiconductors [1-3]. Nevertheless, the a priori determination of the conditions leading to the growth of a compound or an alloy is still a problem. There is no simple or general model for molecular beam epitaxy. People involved in the growth of compound semiconductors rely on different rules of thumb to have an idea of the temperature of the cells they should try in order to get the composition and the growth rate they want to obtain. For example, in the case of III V compounds, it is an experimental fact that the group III molecule, which corresponds to a low pressure element, governs the growth rate and that the beam of group $\mathrm{V}$ element can be in a large excess without preventing the growth of the III V compound [4]. Moreover, a large use is made of the concept of sticking coefficient: it is well known that the sticking coefficient of an element having a high equilibrium vapour pressure is low, but no way exists to calculate this sticking coefficient starting with the published thermodynamic data [5]. The reason for this absence of general thermodynamic treatment is due to the fact that molecular beam epitaxy has been considered from the start as an out of equilibrium process, [6-7]. This means that the growth is considered to be governed by kinetic barriers and that a lot of intermediate reactions and states of the molecules have to be taken into account, each reaction or species being defined by one or more empirical parameters (incorporation coefficient, life 
time, dissociation constant...). This point of view leads unavoidably to an a posteriori fitting of the parameters. This approach has been disputed, for sometimes, principally by Heckingbottom and collaborators [8-10] and by an in depth analysis of the conditions of epitaxy of III V compounds (GaAs, GaAlAs, etc.) ; they have been able to demonstrate that the molecular beam epitaxy of these compounds obeys the thermodynamical laws. Further, the results obtained in our laboratory on the molecular beam epitaxy of II VI compounds [11-14], namely CdTe, $\mathrm{HgTe}$ and the ternary alloy $\mathrm{HgCdTe}$, leads us to the same conclusion, i.e. there is no kinetic limitation hiding the quasi thermodynamical equilibrium.

\section{Equilibrium.}

Before we deal with the thermodynamical approach of the molecular beam epitaxy, it seems wise to remind what is meant by thermal equilibrium. We consider here the vapour phase which is in equilibrium with a solid compound. The equilibrium relation, in the simple case of II VI compounds, can be written [15-16] :

$$
\underset{\text { Solid }}{\mathrm{AB}} \leftrightarrows \frac{1}{n} \mathrm{~B}_{n}+\mathrm{A}
$$

where $n$ is the polymerization of the B element in the vapour phase ( $n=2$ for column VI).

Far from the melting point, the activities can be taken equal to 1 and the simple mass action law holds :

$$
P_{\mathrm{A}} P_{\mathrm{B}}^{1 / n}=K(T)
$$

\section{pressures over $\mathrm{Cd}$ Te}

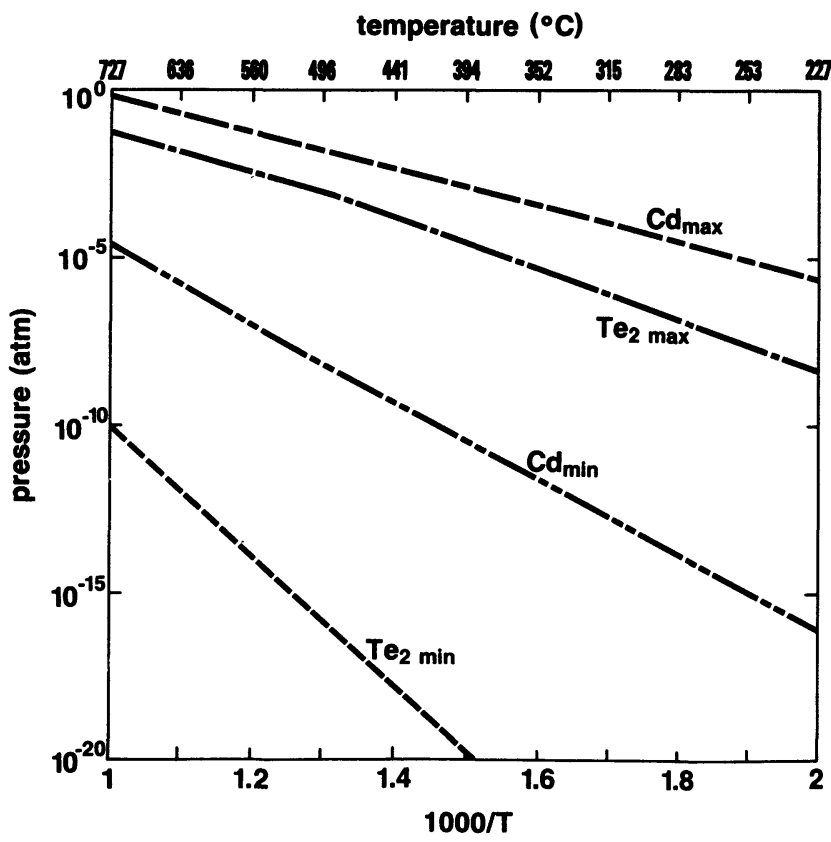

Fig. 1. - Partial pressures of $\mathrm{Cd}$ and $\mathrm{Te}_{2}$ along the three phase curve for cadmium telluride. with the following limitation:

$$
P_{\mathrm{A}}<P_{\mathrm{A}}^{0} \quad P_{\mathrm{B}}<P_{\mathrm{B}}^{0}
$$

where $P_{\mathrm{A}}^{0}$ and $P_{\mathrm{B}}^{0}$ are the pressures above the pure elements $A$ and $B$.

Figures 1 and 2 show the limits of pressures which can be in equilibrium over CdTe or over HgTe. These curves are calculated from values given in table I. In the case of a ternary alloy, say $\mathrm{Hg}_{1-x} \mathrm{Cd}_{x} \mathrm{Te}$ which is an ideal solution [17], the mass action can be written :

$$
\begin{aligned}
P_{\mathrm{Hg}} P_{\mathrm{Te}}^{1 / 2} & =(1-x) K_{\mathrm{HgTe}}(T) \\
P_{\mathrm{Cd}} P_{\mathrm{Te}}^{1 / 2} & =x K_{\mathrm{CdTe}}(T) .
\end{aligned}
$$

\section{pressures over $\mathrm{Hg} \mathrm{Te}$}

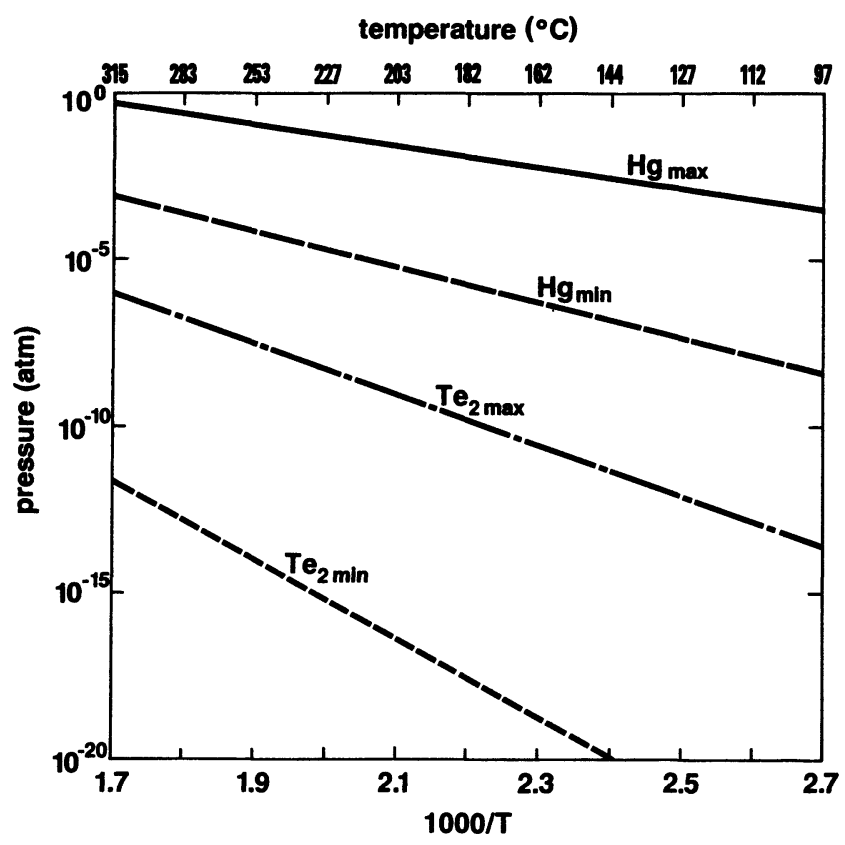

Fig. 2. - Partial pressures of $\mathrm{Hg}$ and $\mathrm{Te}_{2}$ along the threephase curve for mercury telluride.

Table I-1. - Numerical data used to calculate the pressure in atmosphere over pure elements using the relation : $\log _{10} P^{0}=a-\frac{b}{T}$.

\begin{tabular}{|c|c|c|c|l|c|}
\hline Elément & $n$ & $a$ & $b$ & \multicolumn{1}{|c|}{ Comment } & Ref. \\
\hline $\mathrm{Cd}$ & 1 & 5.96 & 5808 & $T<311.5^{\circ} \mathrm{C}$ & 18 \\
$\mathrm{Cd}$ & 1 & 5.12 & 5317 & $T>311.5^{\circ} \mathrm{C}$ & 18 \\
$\mathrm{Te}$ & 2 & 6.87 & 7594 & $T<487^{\circ} \mathrm{C}$ & 24 \\
$\mathrm{Te}$ & 2 & 4.72 & 5960 & $T>487^{\circ} \mathrm{C}$ & 18 \\
$\mathrm{Hg}$ & 1 & 5.03 & 3157 & & 18 \\
\hline
\end{tabular}


Table I-2. - Mass action law coefficients (pressures in atmospheres) : $\log _{10}\left[P_{M}\left(P_{\mathrm{Te} 2}\right)^{1 / 2}\right]=c-\frac{d}{T}$.

\begin{tabular}{|c|c|c|c|}
\hline Compound & $c$ & $d$ & Ref. \\
\hline CdTe & 9.82 & 15000 & 17 \\
HgTe & 9.33 & 9105 & 17 \\
\hline
\end{tabular}

The equilibrium curves calculated for $x=0.2$ are shown in figure 3 . It should be noticed that the maximum $\mathrm{Cd}$ pressure over this $\mathrm{HgCdTe}$ is much lower than over pure cadmium. This is in agreement with the measurements by Brebrick et al. [18, 19]. Given the vapour pressures of the elements and the $K(T)$ of the compounds it is easy to calculate a set of vapour pressures in equilibrium with a binary compound or a ternary alloy.

In this case, the solid is bombarded by the different gases with fluxes which are linked to their pressures by the following relation :

$$
S_{\mathrm{A}}=P_{\mathrm{A}}\left(2 \Pi M_{\mathrm{A}} k T\right)^{-1 / 2}
$$

where $P_{\mathrm{A}}$ is the pressure of species $\mathrm{A}$ and $M_{\mathrm{A}}$ its molecular mass, $T$ is the temperature of the system. Because we are at exact equilibrium, there is no net growth or evaporation of the solid. Thus the evaporating flux $J_{\mathrm{A}}$ compensates exactly for the impiging flux $S_{\mathrm{A}}$ :

$$
J_{\mathrm{A}}=S_{\mathrm{A}} \text {. }
$$

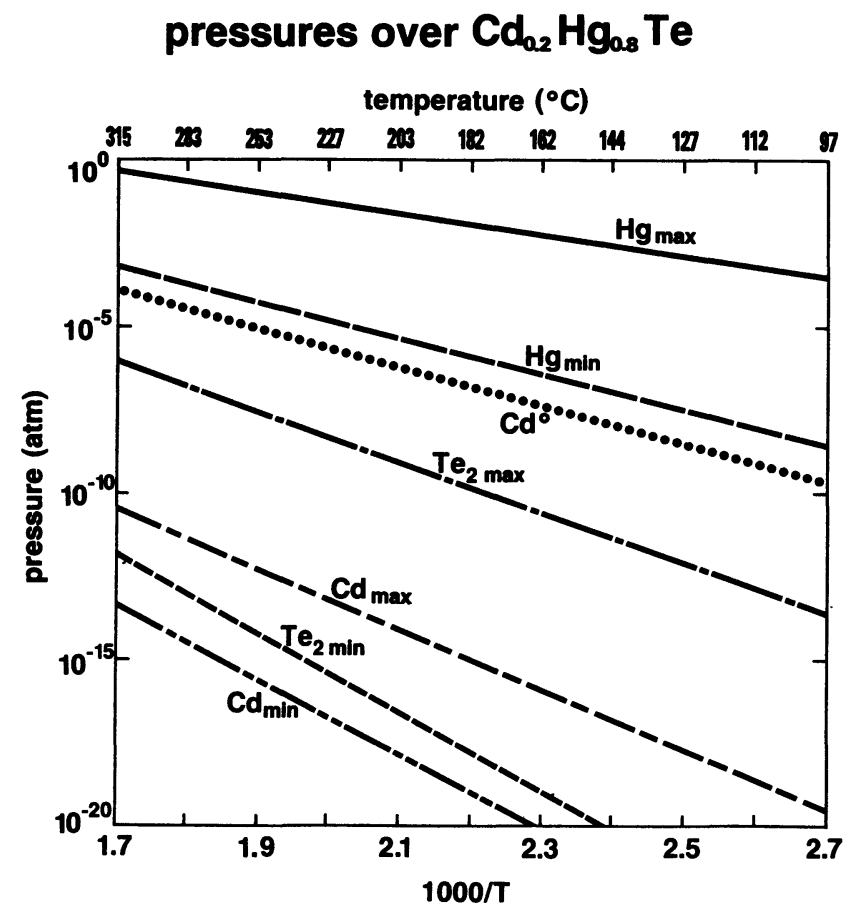

Fig. 3. - Partial pressures of $\mathrm{Hg}, \mathrm{Cd}$ and $\mathrm{Te}_{2}$ along the three-phase curve for $\mathrm{Hg}_{0.8} \mathrm{Cd}_{0.2} \mathrm{Te}$.
In the case of $\mathrm{MBE}$, the flux $S_{\mathrm{A}}$ is the impinging flux from the source on the growing layer and $J_{\mathrm{A}}$ is its evaporating flux.

This simple remark is the base of the model shown in the next section.

\section{Detailed balance model of molecular beam epitaxy.}

3.1 CASE OF A BINARY COMPOUND. - For a sake of simplicity, we will demonstrate the model considering the growth of a binary compound. In order to elaborate the compound $\mathbf{A B}$, the elements $\mathrm{A}$ and $\mathrm{B}$ should react and in the following we suppose, as explained in paragraph 1 , that the reaction is fast enough so that thermal equilibrium is not hindered by kinetics. To introduce the time in a thermodynamically based model, we simply consider that the growth rate will be limited by arrival rate of the species at the growing surface. These assumptions made, we can now write down the equations of the conservation of the mass of the different species :

$$
\begin{aligned}
& \frac{\mathrm{d} A}{\mathrm{~d} t}=S_{\mathrm{A}}-J_{\mathrm{A}} \\
& \frac{\mathrm{d} B}{\mathrm{~d} t}=n S_{\mathrm{B}}-n J_{\mathrm{B}}
\end{aligned}
$$

where $\frac{\mathrm{d} A}{\mathrm{~d} t}$ and $\frac{\mathrm{d} B}{\mathrm{~d} t}$ are the rates of incorporation $\left(\mathrm{cm}^{-2} \mathrm{~s}^{-1}\right)$ of $A$ and $B$ in the solid phase. If the compound $\mathrm{AB}$ may be formed (and if there is no competing reaction) we should have :

$$
v=\frac{\mathrm{d} A}{\mathrm{~d} t}=\frac{\mathrm{d} B}{\mathrm{~d} t} .
$$

Furthermore, we know that the compound $\mathrm{AB}$ at equilibrium evaporates with fluxes $J_{\mathrm{A}}$ and $J_{\mathrm{B}}$ which are linked by a transformation of the mass action law (2) using equation (6) :

$J_{\mathrm{A}} J_{\mathrm{B}}^{1 / n}=K(T)\left(2 \Pi M_{\mathrm{A}} k T\right)^{1 / 2}\left(2 \Pi n M_{\mathrm{B}} k T\right)^{1 / 2 n}$

which can be more conveniently rewritten as :

$$
J_{\mathrm{A}} J_{\mathrm{B}}^{1 / n}=G(T)
$$

$T$ being here the substrate temperature.

We assume that, during the growth, the evaporation fluxes are the same than at equilibrium, they depend only on the surface composition and on the temperature. Thus the final set of equations for the quasi equilibrium growth of a binary compound is :

$$
\begin{gathered}
v=S_{\mathrm{A}}-J_{\mathrm{A}} \\
v=n S_{\mathrm{B}}-n J_{\mathrm{B}} \\
J_{\mathrm{A}} J_{\mathrm{B}}^{1 / n}=G(T) .
\end{gathered}
$$

If the thermodynamical constant $K(T)$, thus $G(T)$, is known these equations can be solved. The follow- 
ing calculations in this paper rely on the published values of enthalpies and entropies of sublimation of pure elements and on chemical potentials of compounds (see Table I). No room is left for fitting parameter.

One of the solution of equations (13) consists for each substrate temperature, to choose a growth rate $v$, a couple of $J_{\mathrm{A}}$ and $J_{\mathrm{B}}$ values coupled by (11) and lying inside their domain of existence. It is then straightforward to calculate the flux $S_{\mathrm{A}}$ and $S_{\mathrm{B}}$ in the beams and hence the cell temperatures to use to grow the layer. An example of such a calculation is shown for the growth of a CdTe layer in figure 4 . The cells, supposed to be acting as a Knudsen evaporation cell, have a geometry defined by their diameter $(1.8 \mathrm{~cm})$ and their distance to the substrate $(12 \mathrm{~cm})$.

\section{M.B.E. of $\mathrm{Cd} \mathrm{Te}$ $V=6 \AA / s$}

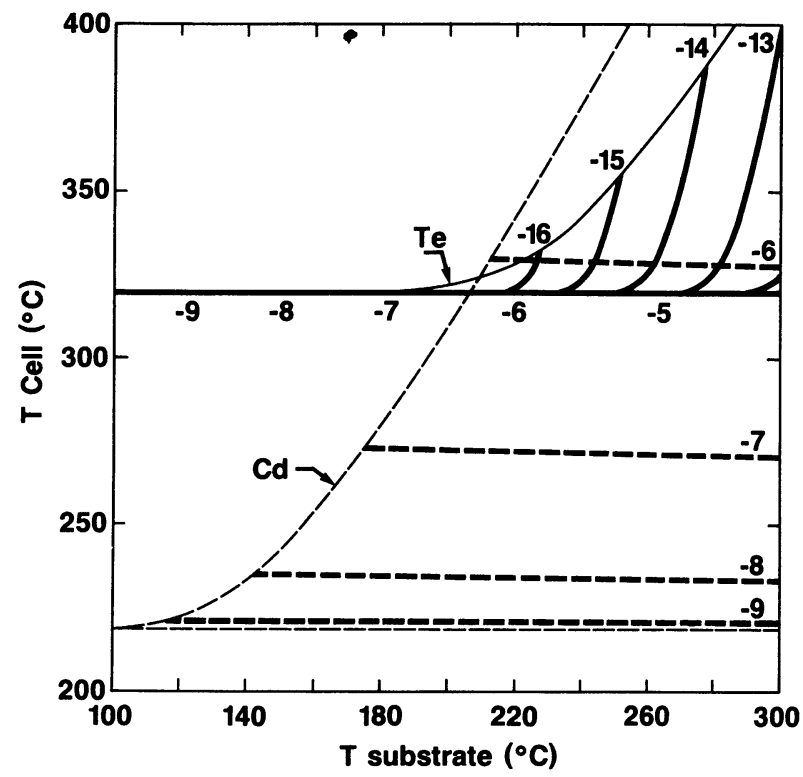

Fig. 4. - Calculated $\mathrm{Cd}$ and $\mathrm{Te}$ cell temperatures for the growth of CdTe at $6 \AA \mathrm{s}^{-1}$. Labels on the curves are the power of ten of cadmium equilibrium pressures (atm) over the growing cadmium telluride.

Each curve $\mathrm{Cd}$ or $\mathrm{Te}$ is parametrized by a label which gives the power of ten of the cadmium equilibrium pressure, in atmosphere, over the actual growing compound. From these curves the following conclusions may be drawn :

1) Under a substrate temperature of approximately $200{ }^{\circ} \mathrm{C}$, the growth rate is controlled by the tellurium beam. At $200^{\circ} \mathrm{C}$, the Te cell being at $322{ }^{\circ} \mathrm{C}$, the $\mathrm{Cd}$ cell can be adjusted between $220^{\circ} \mathrm{C}$ and $310^{\circ} \mathrm{C}$ leading from « tellurium rich » $\mathrm{CdTe}$ to « cadmium rich » CdTe.
2) It is impossible to grow CdTe with two cells at temperature less than $100^{\circ} \mathrm{C}$, because none of the species in excess evaporates, so the control of the beam should be so precise that it is unachievable.

3) Above a substrate temperature of $200{ }^{\circ} \mathrm{C}$, which is the most interesting case because at these temperatures it is safe to ascertain that kinetics is negligible in the sense that perfect monocrystals are grown [10], both materials can evaporate and the growth rate is controlled by the element which has the lower equilibrium pressure, i.e. the cadmium flux for a tellurium rich material or by the tellurium flux for a cadmium rich material.

The conclusions 1 and 3 are verified experimentally with CdTe, nevertheless it is not possible to reach the minimum controlable temperature defined in 2, because the CdTe growth has a poor cristallinity at a higher temperature than the calculated minimum.

3.2 EXTENSION OF THE MODEL. - The extension of the model to a ternary alloy is straightforward using the relations (4) and (5) rewritten with the J's. Taking as an example the alloy $\mathrm{Hg}(1-x) \mathrm{Cd}(x)$ $\mathrm{Te}$, the equations are the following :

$$
\begin{aligned}
(1-x) \cdot v & =S_{\mathrm{Hg}}-J_{\mathrm{Hg}} \\
x \cdot v & =S_{\mathrm{Cd}}-J_{\mathrm{Cd}} \\
v & =2 S_{\mathrm{Te}}-2 J_{\mathrm{Te}} \\
J_{\mathrm{Hg}} J_{\mathrm{Te}}^{1 / 2} & =(1-x) \cdot G_{\mathrm{HgTe}}(T) \\
J_{\mathrm{Cd}} J_{\mathrm{Te}}^{1 / 2} & =x \cdot G_{\mathrm{CdTe}}(T) .
\end{aligned}
$$

They can easily be solved using a computer. Let us first address the following problem : to calculate the beams $S_{\mathrm{Hg}}, S_{\mathrm{Cd}}$ and $S_{\mathrm{Te}}$ needed to grow the alloy with a given $x$ at a given rate $v$, the substrate temperature being a parameter. Figure 5 shows the calculated cell temperatures to grow $\mathrm{Hg}_{0.8} \mathrm{Cd}_{0.2} \mathrm{Te}$ at a rate of $6 \AA \mathrm{s}^{-1}$. The parameters on the curves are the power of ten of the mercury equilibrium pressures (in atm) over the actual alloy. The curves have been calculated for a large domain of temperature in which the parameters may not have a physical meaning in the context of MBE. For example, even at $100^{\circ} \mathrm{C}$ the maximum mercury beam under which the compound may exist represents a consumption of $50 \mathrm{~kg} \mathrm{~h}^{-1}$ ! This has no meaning in a MBE system. Starting with a set of curves of the type displayed in figure 5 and calculated for different growth rates and $x$ values, the following conclusions may be drawn.

- Up to $200{ }^{\circ} \mathrm{C}$ the growth rate is controlled by the tellurium beam and the $x$ value by the ratio of the $\mathrm{Cd}$ beam to the Te beam.

- At higher temperature evaporation of the tellurium should be accounted for, especially at 


\section{M.B.E. of $\mathrm{Cd}_{0.2} \mathrm{Hg}_{0.8} \mathrm{Te}$ $v=6 \AA / s$}

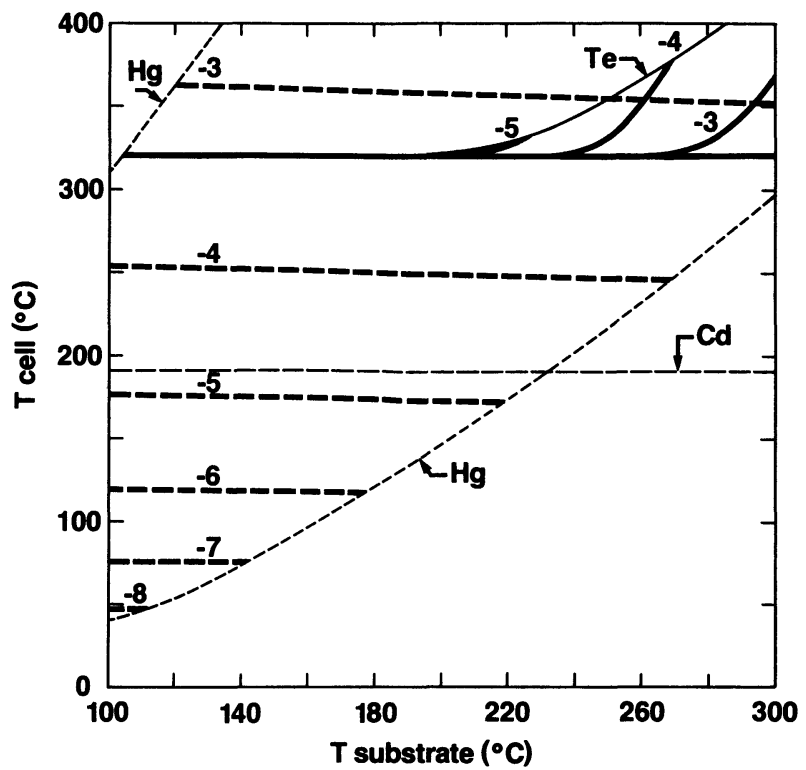

Fig. 5. - Calculated $\mathrm{Cd}, \mathrm{Hg}$ and $\mathrm{Te}$ cell temperatures for the growth of $\mathrm{Hg}_{0.8} \mathrm{Cd}_{0.2} \mathrm{Te}$ at $6 \AA \mathrm{s}^{-1}$. Labels on the curves are the power of ten of the mercury equilibrium pressures (atm) over the growing CMT.

relatively low mercury beam intensity which is always the experimental case.

These predictions are verified by experiments. For example and to give an idea of the precision of the model for MBE growth of CMT, we obtain a rate of $6 \AA \mathrm{s}^{-1}$ and $x=0.2$ on a substrate heated at $180^{\circ} \mathrm{C}$ with a tellurium cell regulated at $332^{\circ} \mathrm{C}$ and a cadmium cell regulated at $190{ }^{\circ} \mathrm{C}$ to be compared with the predicted values $T_{\mathrm{Te}}=320$ and $T_{\mathrm{Cd}}=$ $190{ }^{\circ} \mathrm{C}$ and knowing that we are in the lower range of mercury vapour pressure. The slight difference in the tellurium cell temperature is likely due to a departure of the theoretical Knudsen emissivity and the difficulty to get the real temperature of the cell.

A second problem which can be solved starting with equations (15) to (19) is the following : given the present fluxes $S$ and the substrate temperature $T_{\mathrm{S}}$ find the growth rate and the $x$ value of the alloy, if any. Figure 6 shows the result of such a calculation made for $\mathrm{CdHgTe}$ and three different tellurium cell temperatures. The important points to notice are :

- At $T_{\mathrm{S}}<200{ }^{\circ} \mathrm{C}$, the Te cell governs the growth rate and the $x$. This is a very sensitive parameter. In order to control the $x$ to the precision required for infrared imaging, the temperature of the tellurium cell should be kept constant within $0.1{ }^{\circ} \mathrm{C}$. The same conclusion hold for the Cd cell, the $x$ being in fact controlled by the ratio of the $\mathrm{Cd}$ to the Te fluxes.

- A gap exists for $T_{\mathrm{s}}$ from approximately $195^{\circ} \mathrm{C}$
M.B.E. of $\mathrm{Hg}_{1-\mathrm{x}} \mathrm{Cd}_{\mathrm{x}} \mathrm{Te}$

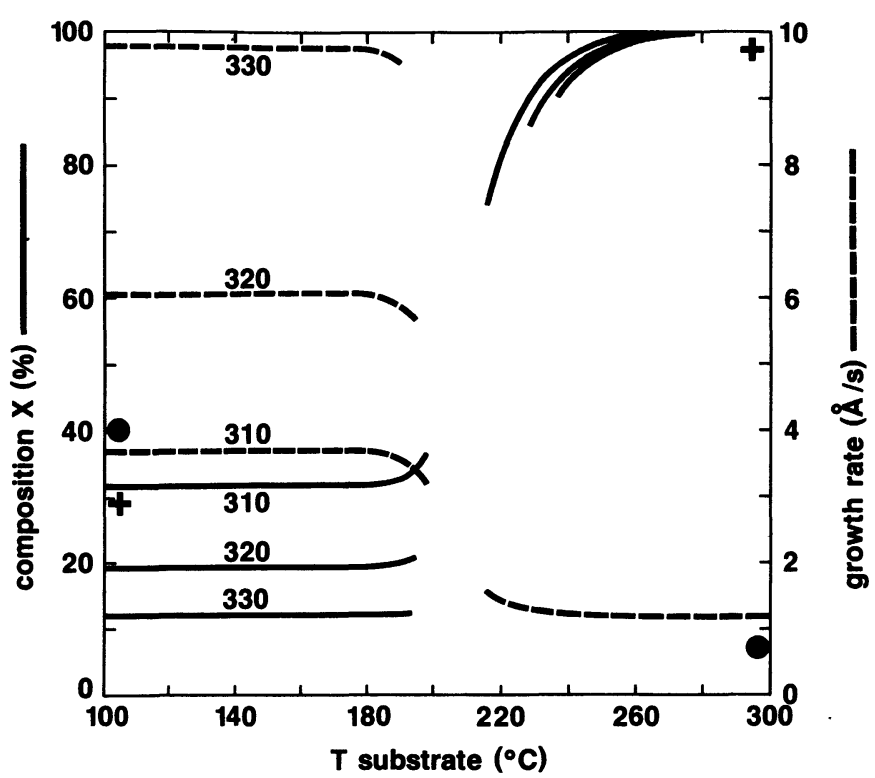

Fig. 6. - Growth rate and composition of CMT for different tellurium cell temperatures $\left(310,320\right.$ and $\left.330{ }^{\circ} \mathrm{C}\right)$ at $T_{\text {cell }}(\mathrm{Hg})=140^{\circ} \mathrm{C}$ and $T_{\text {cell }}(\mathrm{Cd})=190^{\circ} \mathrm{C}$ for different substrate temperatures. Experimental points at

$$
T_{\text {cell }}(\mathrm{Te})=310^{\circ} \mathrm{C}: \cdot \text { growth rate }+ \text { composition } .
$$

to $210-240^{\circ} \mathrm{C}$ depending on the Te flux. In this region, there is a lack of mercury compared to the Te flux, then Te precipitates appear. The experiment shows that in this range of temperature, the RHEED turns always to the polycristalline pattern.

- At higher temperature, the tellurium reevaporates (not the cadmium !). The growth rate is lower and governed by the cadmium flux. The $x$ value goes to 1 .

The experimental points, in figure 6 , confirm the predictions of the model concerning the effect of the substrate temperature.

3.3 INCORPORATION COEFFICIENT. - The model allows us to calculate the incorporation coefficient $C$ of a species. $C$ is defined as the ratio of the number of atoms participating to the growth of the layer to the number of incident atoms of the considered species. Taking as an example the incorporation coefficient of $\mathrm{Hg}$ in the growth of CMT, we have, using the definition :

$$
C_{\mathrm{Hg}}=\frac{S_{\mathrm{Hg}}-J_{\mathrm{Hg}}}{S_{\mathrm{Hg}}} .
$$

From equations (19) and (20) we draw :

$$
C_{\mathrm{Hg}}=\frac{(1-x) v}{S_{\mathrm{Hg}}} \text {. }
$$


This important relation shows that the incorporation coefficient is essentially variable. The model brings us something more : it can tell us, for example, whether it is possible to grow the alloy with a given $x, v$ and $S_{\mathrm{Hg}}$. Figure 7 shows that at $6 \AA \mathrm{s}^{-1}$ and a cadmium cell adjusted to grow CMT at $x=20 \%$ (for $T_{\mathrm{S}}=180^{\circ} \mathrm{C}$ ) the incorporation coefficient is between $10^{-3}$ and $10^{-2}$ depending on the mercury cell temperature. These results are in agreement with the experiment, moreover, if the $\mathrm{Hg}$ temperature cell is fixed at $120^{\circ} \mathrm{C}$, it is impossible, on a substrate held at $200^{\circ} \mathrm{C}$, to grow CMT at $x=20 \%$ at $v=6 \AA \mathrm{s}^{-1}$ (lack of $\mathrm{Hg}$ and Te precipitates). We

\section{$\mathrm{Hg}$ incorporation coefficient}

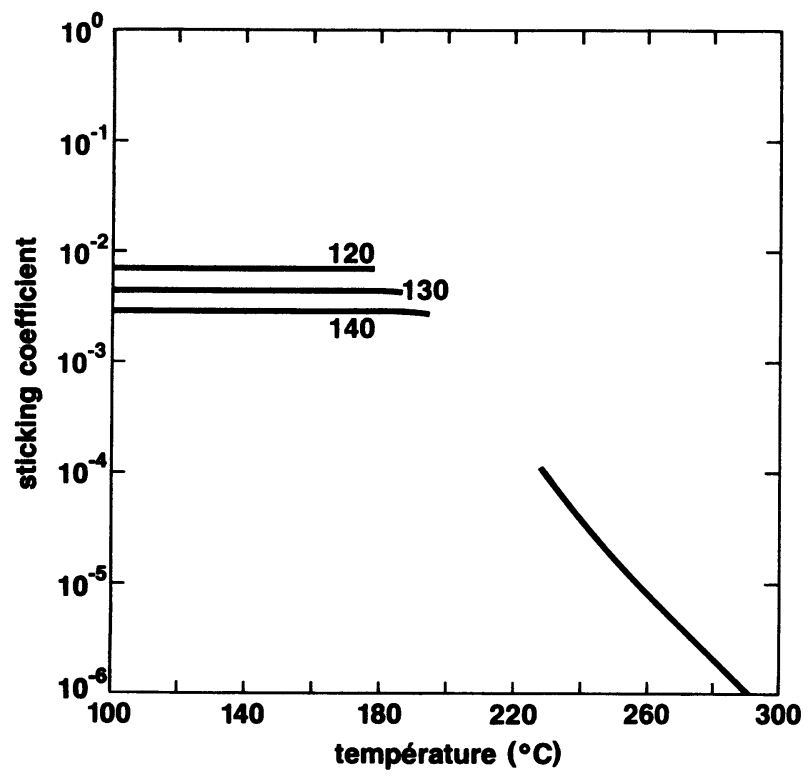

Fig. 7. - Incorporation coefficient of mercury as a function of substrate temperature for three different mercury cell temperatures $\left(120,130\right.$ and $\left.140{ }^{\circ} \mathrm{C}\right)$ at

$$
T_{\text {cell }}(\mathrm{Cd})=190^{\circ} \mathrm{C} \text { and } T_{\text {cell }}(\mathrm{Te})=320^{\circ} \mathrm{C} \text {. }
$$

fall in the gap which has been previously explained. The low incorporation coefficient of mercury in the conditions needed to grow CMT rises technological problems because the consumption of the mercury cell can reach up to $100 \mathrm{~g} \mathrm{~h}^{-1}$ ! To have the best yield, in term of mercury consumption, it is necessary to grow fast at the lowest possible temperature.

\section{Conclusions.}

We have established a simple model of molecular beam epitaxy based on a detailed balance of the fluxes at the growing surface. The evaporating fluxes are assumed to obey the mass action law of the actual growing alloy. It means that the impinging species quickly acquire the substrate temperature ; this has been experimentally shown [21]. Such a model can work only if there is no kinetic hindrance of the reactions predicted by the thermodynamics, we conclude that this is the case with II VI semiconductors as the previsions of the model are fulfilled by the experimental results. We have shown that, at low temperature the growth rate of CMT is controlled by the tellurium, the composition $x$ by the ratio of the cadmium to the tellurium flux. We have explained that it is experimentally impossible to grow CMT at a temperature higher than $200^{\circ} \mathrm{C}$ and we have calculated the incorporation coefficient of mercury and shown that it depends of the flux of the tellurium cell via the growth rate. In the case of the growth of a $\mathrm{HgTe}-\mathrm{CdTe}$ superlattice the model predict that the mercury shutter may stay open and that only the cadmium beam has to be modulated. This has been experimentally checked.

\section{Acknowledgments.}

I would like to thank people of the LETI/MBE group : C. Fontaine and J. Piaguet for experimental results and $Y$. Demay and A. Million for many stimulating discussions and helpful inputs. This work has been supported by DRET, Ministry of defence, who is acknowledged for the permission to published this paper.
[1] Proceedings 5th molecular beam epitaxy workshop J. R. Arthur Ed. (1984). A.V.S. pub.

[2] Molecular beam epitaxy and clean surfaces techniques 2nd Int. Symposium. Tokyo (1982). R. Veda Ed.

[3] Proceedings of the Int. conf. on MBE San Francisco 1984, J. Vac. Sci. Technol. B 3 (2) (1985).

[4] Сно, А. Y., Thin Solid Films 100, 1983, p. 291-317.

[5] Faurie, J. P., Million, A., Boch, R., Tissot, J. L., J. Vac. Sci. Technol. A 1 (1983) 1593.
[6] Cho, A. Y., Arthur, J. R., in Progress in Solid State Chemistry, G. Somorjai, J. McCaldin Ed. (Pergamon Press, Oxford) 1975, Vol. 10.

[7] Chang, L. L., Ludecke, R., in Epitaxial Growth A, J. W. Matthews Ed. (Academic Press, New York) 1975, p. 37.

[8] Heckingbottom, R., Todd, C. J., Davies, G. J., J. Electrochem. Soc. 127 (1980) 444.

[9] Heckingbottom, R., Davies, G. J., J. Cryst. Growth 50 (1980) 644. 
[10] Heckingbottom, R., Davies, G. J., Prior, K. A., Surf. Sc. 132 (1983) 376-389.

[11] Faurie, J. P., Million, A., J. Crystal Growth 54 (1981) 582.

[12] Faurie, J. P., Million, A., Piaguet, J., J. Crystal growth 59 (1982) 10.

[13] Faurie, J. P., Million, A., Piaguet, J., Appl. Phys. Lett. 41 (1982) 713.

[14] Gailliard, J. P., Proceedings of « $3^{\mathrm{e}}$ sémi naire français d'épitaxie par jets moléculaires » p. 9, F. Arnaud d'Avitaya Ed. (1984).

[15] Goldfinger, P., Jeunehomme, M., Trans. Faraday Soc. 59 (1963) 2851.

[16] Lorentz, M. R., Physics and Chemistry of II VI Compounds, Ed. M. Aven, J. S. Prener (NorthHolland Pub. Co.) 1967.

[17] Tse Tung, Golonka, L., Brebrick, R. F., J. Electrochem. Soc. 128 (1981) 451.
[18] Brebrick, R. F., Su, C. H., LiaO, P. K., in Semiconductors and semimetals (Acad. Press) 1983, Vol. 19.

[19] Schwartz, J. P., Tung, T., Brebrick, R. F., J. Electrochem. Soc. 128 (1981) 438.

[20] Baba, S., Horita, H., Kinbara, A., Appl. Phys. Lett. 49 (1978) 3682.

[21] Arthur, J. R., Brown, T. R., J. Vac. Sci. Technol. 12 (1975) 200.

[22] Heckingbottom, R., in Proc. NATO-ASI School on $M B E$ and heterostructures (Martinus Nijhoff Pub. Erice, Italy) 1983.

[23] TABe, M., KaJiYama, K., in our reference [2] p. 187.

[24] NeSmeyanov, A. N., Vapour pressure of the chemical elements (Elsevier Pub.) 1963. 